\title{
APPLICATION OF THE APPROACH TO CREATE AN INFORMATION CONSTRUCTION MODEL AT THE PRE-DESIGN STAGE OF INVESTMENT AND CONSTRUCTION PROJECTS
}

\author{
${ }^{1}$ Chertkov O.Y., PhD, Assistant Professor, \\ chertoleg1954@gmail.com, ORCID: 0000-0002-7206-4535 \\ ${ }^{1}$ Khokhriakova D.O., PhD, Assistant Professor, \\ khokhriakova.do@knuba.edu.ua, ORCID: 0000-0002-9257-5703 \\ ${ }^{1}$ Kyiv National University of Civil Engineering and Architecture \\ 31, Povitroflotsky Ave., Kyiv, 03037, Ukraine
}

\begin{abstract}
At the present stage of development of the construction industry, steps to improve the efficiency of investment and construction projects can no longer be considered outside the context of construction information modeling technologies. Today, one of the main criteria for optimizing work on investment and construction projects is to reduce the time spent searching, working out and agreeing on spatial, financial, and temporal information about the construction object, therefore, the issue of the correct organization of information modeling of a construction site is quite relevant.

In most cases, the design assignment is drawn up in the form given in Appendix B DBN A 2.2-22014 and is formal in nature. The presence of a design assignment, drawn up using the tools proposed below, reflects the thoroughness of the customer's elaboration of an investment and construction project, and reduces the risks of its implementation. The proposed methodology is based on three components of counter design, such as disaggregation, aggregation, and decomposition, from which its name - DAD - approach comes from. Allocation of structural elements in the structure of a building by disaggregation (analysis of alternative options) allows to create its model in the form of a hierarchical structure consisting of detailed and mutually synchronized parts - the configuration of the building. In accordance with the configuration of the construction site, hierarchical numbering is further reflected at all stages of design and in all its sections, incl. stamps of drawings and local estimates. This creates a unified system of interconnection and control of project sections. The creation of a construction site configuration in the form of a tree model with hierarchically numbered elements at the pre-design stage allows it to be applied at subsequent stages of the life cycle of a construction object in information modeling technologies. The use of the DAD - approach in counter-design is intended to increase the efficiency of the implementation of investment and construction projects.
\end{abstract}

Keywords: investment and construction project, information modeling of construction, predesign stage, DAD - approach, disaggregation.

Introduction. At the current stage of development of the construction industry, steps to improve the efficiency of investment construction projects (ICP) can no longer be considered outside the context of site information modeling (SIM) technologies. The end result of the MTC is to ensure the safety and efficiency of implementation during all stages of the life cycle of the construction cycle.

Today, one of the main criteria for optimizing the work on the ICP is to reduce the time to search for, process and coordinate spatial, financial and temporal information about the construction site, so the question of proper organization of the ICP is quite relevant.

According to the already established practice, the life cycle of a project is determined as the time between the inception of the project and the moment of its finalization. However, even within the national legal framework, there is no single approach to dividing the project implementation process into stages, and there is a mismatch of terminology and stages of the life cycle between national and European international standards.

Bulletin of Odessa State Academy of Civil Engineering and Architecture, 2021, no. 85, page 137-144 
The ICP implementation process can be divided into four stages: pre-investment research, investments stage, operation and liquidation of the facility. Moreover, the authors attribute the development of design and estimate documentation (DED) to the investment stage. In this paper, we will focus on the first two.

The experience of pre-investment research shows that construction projects are developed on the basis of a deterministic model, which incorporates provision for certain sales of construction products, investment and time costs. Uncertainties that are present and drive constant changes in the project hinder the achievement of these indicators. Therefore, only 5\% of ICP are implemented according to the usage of pre-planned resources and adherence to time and cost indicators.

The aforementioned indicates that the development of methods to improve the efficiency of ICP during conditions of uncertainty possess great practical and scientific interest.

Analysis of recent research and publications. Methodical and theoretical problems of optimizing the cost and risks of investment projects are reflected in the following papers such as S.A. Ushatsky, V.O. Pokolenko, O.A. Tuhay [1], R.B. Tian [2], V.F. Zalunin, E.Yu. Antipenko, V.I. Donenko [3] and others [4].

Decision-making models on investing in the construction industry have been considered by G.V. Gorchakivska, G.I. Semenova, B.O. Michels, B.M. Lytvyn and others [5].

The work of O.A. Tuhay [6] and T.O. Stadnikova [7, 8], which defines the classification criteria and proposed a scheme that systematizes the factors of uncertainty in the construction industry, proposed a system of methods of formalized description of uncertainties, studied the dependence of ICP estimation models on their uniqueness.

In the framework of research on improving the technology of information modeling of buildings (BIM) using the concept of "construction management template", conducted by O.I. Menelyuk and O.L. Nikiforov [9], proposed the basic and functional schemes of use of information tools in management and the scheme of interaction of construction participants in knowledge management using the presented concept.

According to the authors, the above-mentioned publications do not sufficiently disclose the issues of creating an information construction model at the pre-project stage of investment and construction projects.

The research purpose. Proposal for the use of a tool for the data preparation for construction at the pre-investment stage to improve the efficiency of the ICP.

Research methodology. At the pre-investment stage, the customer faces many uncertainties, the manifestation of which is key to the the effectiveness of construction projects [8]. In this study, uncertainty should be determined in terms of incomplete and inaccurate information about the construction site, such as inadequate provision of details at the design stage of the project.

Pre-investment studies include the process of preparation of a large volume of documents, including but not limited to: project scheme, an agreement between project participants, engineering opinion, report on the results of analysis of alternatives, feasibility study, expert opinion of consulting firm, expert opinion of the investor, project financing agreement, etc.

Legal conflicts that occur during the preparation of urban development conditions and restrictions - the main component of the initial data for design [10], negatively affect the quality of the documents provided and induce emergence of additional uncertainties.

It is important to prepare a scheme of the project, which determines the composition of the construction in the form of an explication and is the basis for further preparation of the design task. Currently, in most cases, the design task is elaborated in the form given in Annex B of DBN A 2.22-2014 and is of a formal nature.

Insufficiently detailed description of the task leads to serious risks and errors during the implementation of the ICP, on the other hand excessively detailed description - to significant time and money consumption, which reduces the effectiveness of project management itself.

The availability of a design task compiled using the tools provided below reflects the thoroughness of the ICP customer's processing and reduces the risk of its implementation.

The proposed methodology (Fig. 1) is based on three components of counter-design, such as

Bulletin of Odessa State Academy of Civil Engineering and Architecture, 2021, no. 85, page 137-144 
disaggregation, aggregation and decomposition, from which the name was derived - DAD approach [11].

Determination of structural elements of the construction object via disaggregation (analysis of alternatives) allows to create the model in the form of a hierarchical structures consisting of detailed and synchronized parts - the configuration of the construction object.

Creating a configuration of the construction object at the initiation pre-project stage allows the customer to better understand the implementation of the ICP, convey to the project executor their ideas, and make more informed decisions, which reduces uncertainty and minimizes changes in the project. Thus the aforementioned faciliaties the achievement of business results.

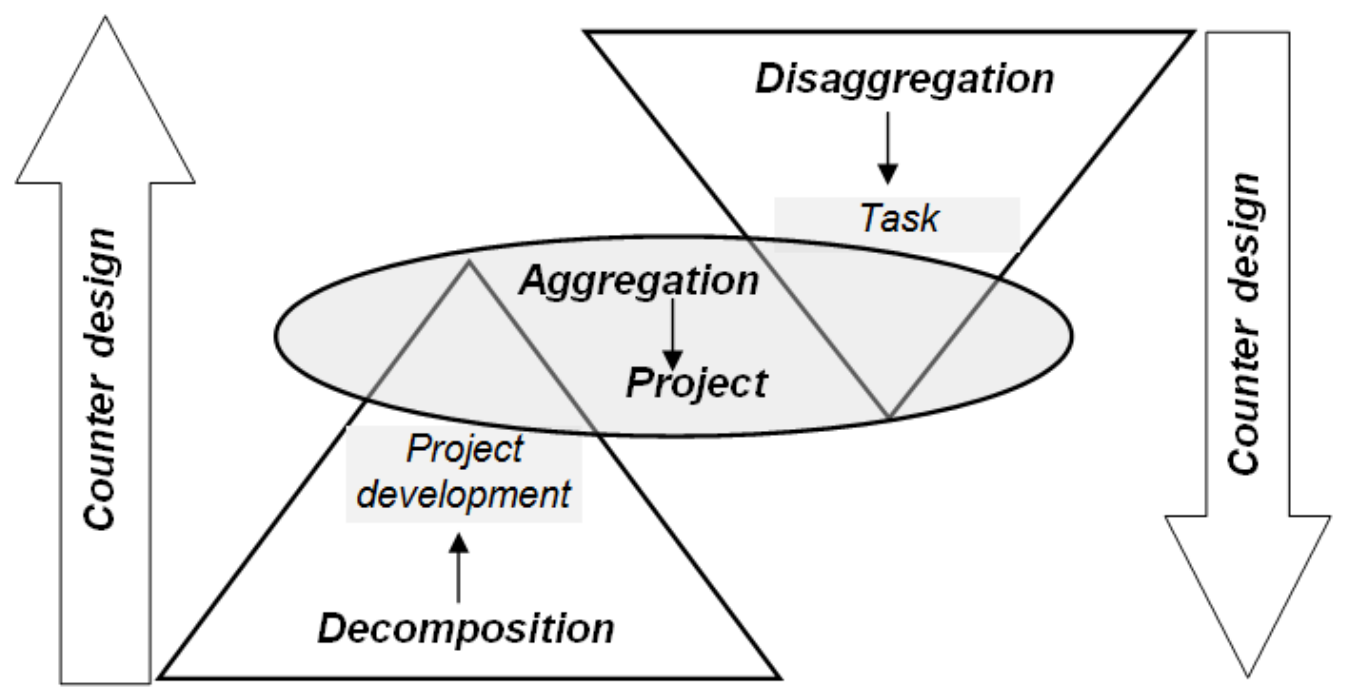

Fig. 1. Scheme of counter-design based on disaggregation, aggregation and decomposition

The initial stage of the DAD approach is the process of disaggregation (Table 1 below):

- thorough analysis of an output data;

- study of documentation of comparative objects;

- usage of experience of other relevant construction organizations;

- application of the methods of expert assessments.

Table 1 - Scheme of the disaggregation process

\begin{tabular}{|c|c|c|}
\hline \multicolumn{3}{|c|}{ Disaggregation } \\
\hline 1. Breakdown of the construction & $\begin{array}{c}\text { 2. Configuration of } \\
\text { the construction } \\
\text { object }\end{array}$ & 3 . Approval by the project \\
\hline $\begin{array}{l}\text { 1.1. Division of the construction } \\
\text { project into separate objects, sub- } \\
\text { objects and significant in } \\
\text { architectural-planning and structural } \\
\text { blocks; } \\
\text { 1.2. Compilation of a tree-like model } \\
\text { with hierarchically numbered } \\
\text { elements. }\end{array}$ & $\begin{array}{l}\text { 2.1. Collection and } \\
\text { accumulation of data } \\
\text { of the construction } \\
\text { objects and its } \\
\text { elements. } \\
\text { 2.2. Optimization of } \\
\text { the primary model. }\end{array}$ & $\begin{array}{l}\text { 3.1. The construction object } \\
\text { is considered configured if } \\
\text { the project is approved by } \\
\text { the manager according to the } \\
\text { following: } \\
\text { - tree-like model with a } \\
\text { hierarchical structure; } \\
\text { - ICP implementation } \\
\text { schedule. }\end{array}$ \\
\hline
\end{tabular}

Examples of building complexes with hierarchically numbered components are shown in Figures 2-3. 


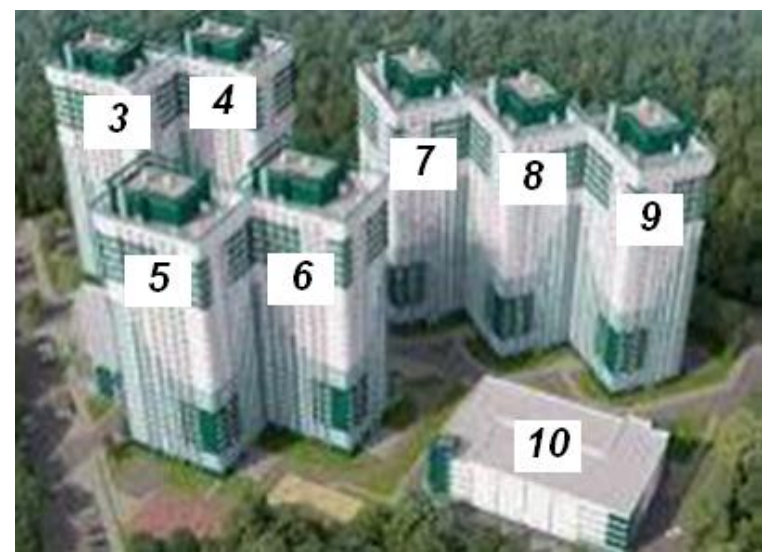

a)

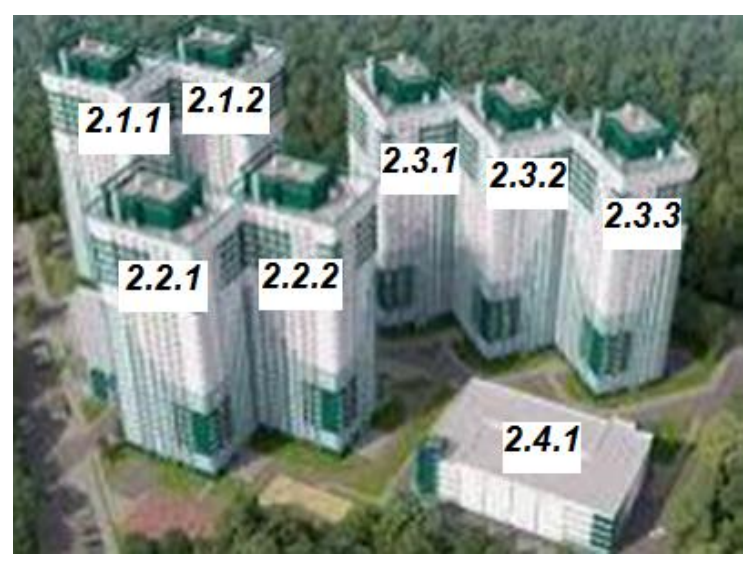

б)

Fig. 2. Example of the breakdown of the second urban complex in the neighborhood: a) in the traditional way; b) with hierarchical numbering

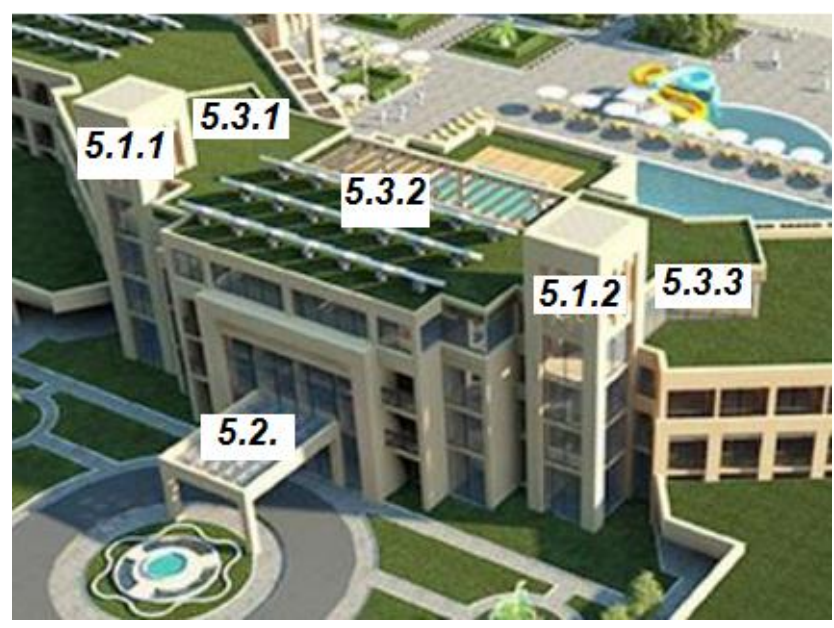

Fig. 3. Example of the breakdown of the entry group

When configuring the structure at the initial pre-design stage, decisions on structural systems, products, materials, utilities and equipment are made by the customer on the basis of open source information from companies - mainly manufacturers and digital libraries.

Research results. The composition of the DED of construction objects based on existing requirements is traditionally:

- end-to-end and disordered;

- documents reflecting current changes in the project are numbered sequentially, i.e. not linked to the original numbering.

Current state of affairs contributes to the filling of communication gaps between the participants of the ICP and the components of the DED. The proposed tool helps the customer to formulate design tasks and differentiate the requirements for the components of the construction object (main purpose, auxiliary and other service purposes, energy consumption, transport and communications, external networks, etc.) so that contractors have more detailed and comprehensive development of its sections.

According to the configuration of the structure (Fig. 4), the hierarchical numbering is further displayed at all stages of a design (EP/TEO, P, RP, P) and in all its sections, including brands of blueprints (TX, AR, AB, KB, KM, OV, VK, ETR, POB, etc.) and local estimates. This creates a unified system of interconnection and control of project sections. 


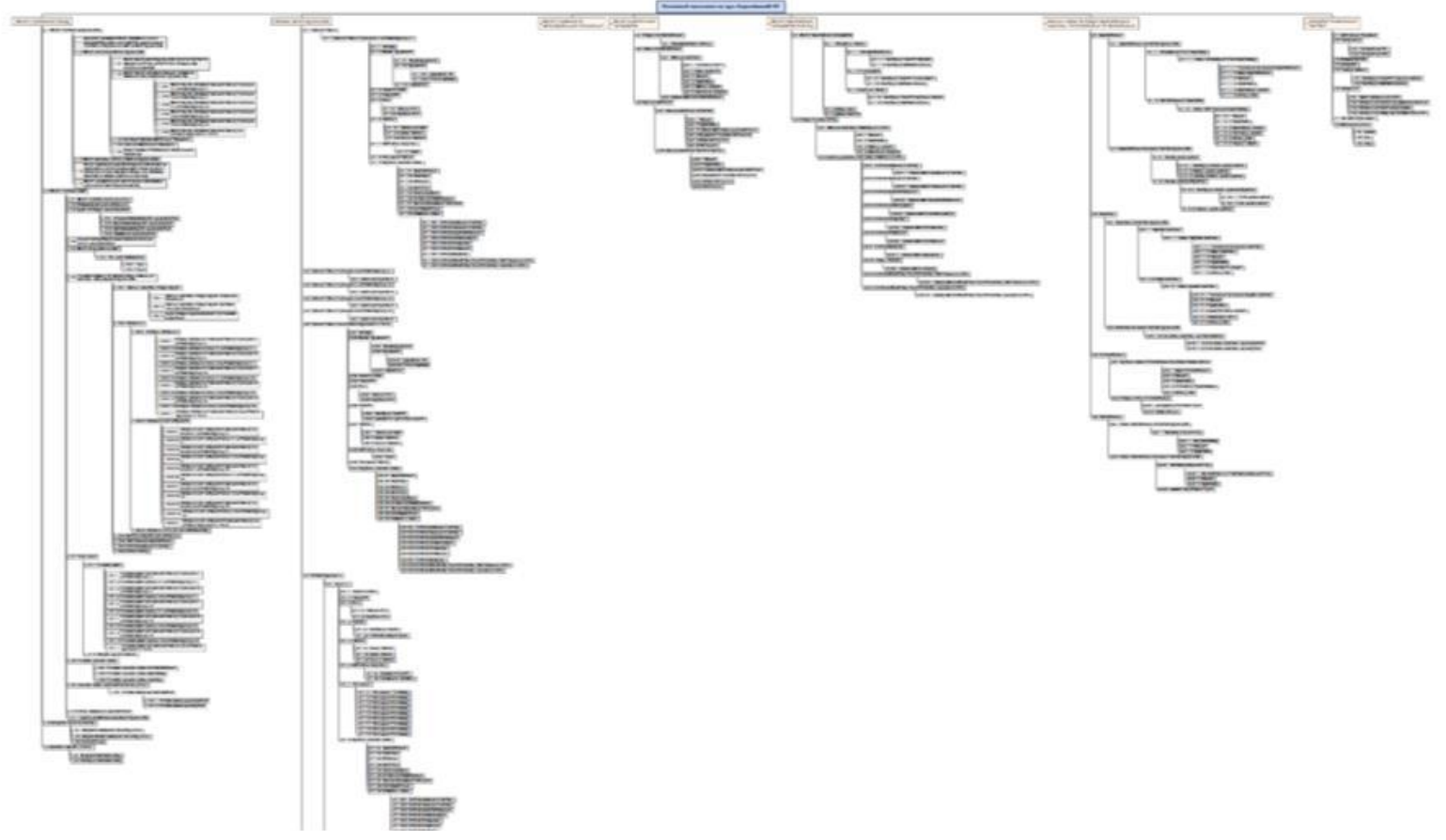

Fig. 4. General view of the configuration of the construction object

Due to the peculiarities of construction production, continuous changes that will be made to the project will be expected.

During the development of the project, clarification of the new information inputs and configurations facilitates interaction between all participants in the process, which reduces the number of errors during the duration of the project, reduces time spent and ensures that the project has the quality of a desired level.

Numerous marketing studies prove that the dependence of forecast costs on forecast efficiency is asymptotic.

As per aforementioned - the effectiveness of the DAD approach can be explained in the figure below (Fig. 5).

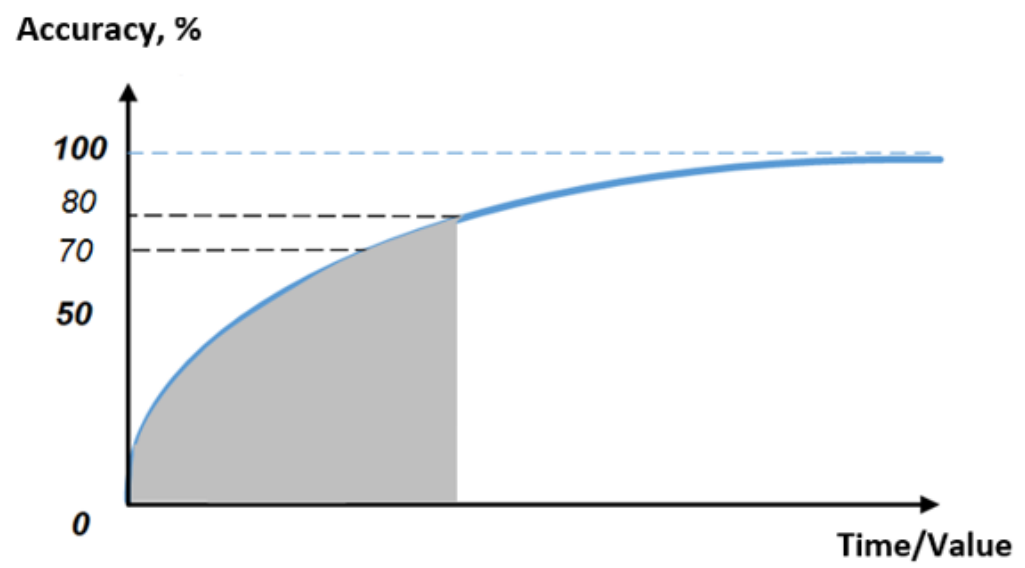

Fig. 5. Dependence of forecasted costs and time verses accuracy

Analyzing the development of the construction object according to the time/cost duration for its development, we can conclude that at the redesign stage by the method of expert assessments in the process of disaggregation can achieve $70-80 \%$ certainty with minimal wastage of time and money.

After the disaggregation is completed, the deployment of the following stages of the preinvestment stage begins: development of the initial business plan for a design project, preparation of 
tender documents, etc.

Conclusion. The use of a DAD approach in counter-design is theoretically reliable and practically realizable and is designed to increase the efficiency of ICP implementation.

The configuration of the construction site can be used as a basis for design documentation, thereby reducing the time for its development.

Thorough study of the composition of construction objects allows us to detail the composition of the future DED as much as possible, forms the structure of local estimates and, accordingly, increases the accuracy of economic calculations.

The creation of a construction site configuration in the form of a tree-like model with hierarchically numbered elements within the framework of pre-investment research allows it to be used in BIM technologies.

Further research will be aimed at improving the SIM technologies using DAD approach for application at subsequent stages of the life cycle of a construction object.

\section{References}

[1] S.A. Ushats'kyy, V.O. Pokolenko, O.A. Tuhay, red. V.O. Pokolenko, Innovatsiyni kontseptual'ni ta formal'no-analitychni instrumenty obgruntuvannya, pidhotovky ta vprovadzhennya budivel'nykh investytsiynykh proektiv: Monohrafiya. Kyiv: Vyd-vo yevrop. un-tu, 2008.

[2] R.B. Tyan, P.YE. Uvarov, S.V. Ivanov, Systemy tekhnolohiy zhyttyevoho tsyklu investytsiyno-budivel'noyi sfery diyal'nosti: monohrafiya. Dnipropetrovs'k: vyd-vo Makovets'kyy YU.V., 2010.

[3] Ye.YU. Antipenko, V.I. Donenko, Printsipy analiza kapital'nykh vlozheniy: Monografiya. Zaporozh'ye: Fazan, 2005.

[4] V.V. Kovalev, O.V. Kirnos, "Sovremennyye podkhody k predvaritel'noy otsenke investitsionno-stroitel'nykh proyektov s uchetom stokhastichnosti protsessov", Noví tekhnologiï v budivnitství, no. 34, pp. 39 - 42, 2018.

[5] M.S. Bilyk, A.S. Bilyk, "Modelyuvannya investytsiynoyi diyal'nosti v budivnytstvi", Stroytel'stvo. Materyalovedenye. Mashynostroenye. Seryya : Sozdanye vysokotekhnolohycheskykh ékokompleksov $v$ Ukrayne na osnove kontseptsyy sbalansyrovannoho (ustoychyvoho) razvytyya, vol. 60, pp. 12-15, 2011.

[6] O.A. Tuhay, T.V. Vlasenko, "Alhorytm poperedn'oyi otsinky dostovirnosti investytsiynykh proektiv u budivel'niy haluzi v umovakh nevyznachenosti", Visnyk Odes'koyi derzhavnoyi akademiyi budivnytstva ta arkhitektury, vol. 82, pp. 141-148, 2021.

[7] T.A. Stadnikova, "Faktory neopredelennosti v stroitel'noy otrasli: klassifikatsiya i analiz ikh vliyaniya na stroitel'nyye proyekty", Sovremennaya ekonomika: problemy $i$ resheniya, Tom 3 (51), pp. 76-86, 2014.

[8] T.A. Stadnikova, "Sistematizatsiya metodov ucheta neopredelennosti pri otsenke ekonomicheskoy effektivnosti investitsionnykh proyektov", Problemy sovremennoy ekonomiki, no. 1 (49), pp. 113 - 116, 2014.

[9] A.I. Meneylyuk, A.L. Nikiforov, Tekhnologiya informatsionnogo modelirovaniya ob"yektov s ispol'zovaniyem shablonov upravleniya stroitel'stvom. Informatsionníy portal NOPRIZ. [Online]. Available: https://nopriz.ru/upload/iblock/015/04_04.pdf.

[10] V.A. Smilka, "Zakonodavchi ta normatyvni pidstavy nadannya vykhidnykh danykh dlya proektuvannya ob"yektiv mistobuduvannya", Suchasni problemy arkhitektury ta mistobuduvannya, vol. 35, pp. 268-272, 2014.

[11] O.YU. Chertkov, V.O. Tsehel'nyy, D.S. Yermolovych, D.YU. Plaksyuk, "Zastosuvannya suchasnoho pidkhodu do pryynyattya orhanizatsiyno tekhnolohichnykh rishen' $\mathrm{V}$ umovakh shchil'noyi zabudovy ta styslykh umov na bazi DAD-pidkhod", Shlyakhy pidvyshchennya efektyvnosti budivnytstva $v$ umovakh formuvannya rynkovykh vidnosyn, vol. 39(2), pp. $71-78,2019$. 


\title{
ЗАСТОСУВАННЯ ПІДХОДУ ДЛЯ СТВОРЕННЯ ІНФОРМАЦЙНОӦ БУДІВЕЛЬНОЇ МОДЕЛІ НА ПЕРЕДПРОЄКТНІЙ СТАДІЇ ІНВЕСТИЦЙННО-БУДІВЕЛЬНИХ ПРОСКТІВ
}

\author{
${ }^{1}$ Чертков О.Ю., к.т.н., доцент, \\ chertoleg1954@gmail.com, ORCID: 0000-0002-7206-4535 \\ ${ }^{1}$ Хохрякова Д.О., к.Т.н., доцент, \\ khokhriakova.do@knuba.edu.ua, ORCID: 0000-0002-9257-5703 \\ ${ }^{1}$ Київський національний університет будівництва і архітектури \\ пр. Повітрофлотський, 31, м. Київ, 03037, Україна
}

\begin{abstract}
Анотація. На сучасному етапі розвитку будівельної галузі кроки 3 підвищення ефективності інвестиційно-будівельних проєктів, вже не можуть розглядатися поза контекстом технологій інформаційного моделювання будови. Сьогодні одним із головних критеріїв оптимізації роботи над інвестиційно-будівельними проєктами є зменшення часу на пошук, опрацювання та узгодження просторової, фінансової та часової інформації про об'єкт будівництва, тому питання коректної організації інформаційного моделювання будівництва цілком актуальне.

У більшості випадків завдання на проєктування складається за формою, наведеною у додатку Б ДБН А 2.2-2-2014, та має формальний характер. Наявність завдання на проєктування складеного за допомогою запропонованого нижче інструментарію відображає ретельність опрацювання замовником інвестиційно-будівельного проєкту та знижує ризики його реалізації. Основою запропонованої методики є три складові зустрічного проєктування, такі як дезагрегація, агрегація та декомпозиція, від яких і походить іiі назва - ДАД - підхід. Виділення в складі будови структурних елементів шляхом дезагрегації (аналізу альтернативних варіантів) дає змогу створити іiі модель у вигляді ієрархічної структури, що складається із детальних та взаємосинхронізованих частин - конфігурацію будови. Відповідно до конфігурації будови ієрархічна нумерація в подальшому відображається на всіх стадіях проєктування i у всіх його розділах, у т.ч. марках креслень і локальних кошторисах. Це створює єдину систему взаємозв'язку і контролю розділів проєкту. Створення конфігурації будови у вигляді деревоподібної моделі 3 ієрархічно пронумерованими елементами на передпроєктній стадії дозволяє застосовувати іiі на подальших етапах життєвого циклу об'єкта будівництва в технологіях інформаційного моделювання. Застосування ДАД - підходу під час зустрічного проєктування покликане збільшити ефективність реалізації інвестиційно-будівельних проєктів.

Ключові слова: інвестиційно-будівельний проєкт, інформаційне моделювання будови, передпроєктна стадія, ДАД - підхід, дезагрегація.
\end{abstract}




\title{
ПРИМЕНЕНИЯ ПОДХОДА ДЛЯ СОЗДАНИЯ ИНФОРМАЦИОННОЙ СТРОИТЕЛЬНОЙ МОДЕЛИ НА ПРЕДПРОЕКТНОЙ СТАДИИ ИНВЕСТИЦИОННО-СТРОИТЕЛЬНЫХ ПРОЕКТОВ
}

\author{
${ }^{1}$ Чертков О.Ю., к.т.н., доцент, \\ chertoleg1954@gmail.com, ORCID: 0000-0002-7206-4535 \\ ${ }^{1}$ Хохрякова Д.А., к.Т.н., доцент, \\ khokhriakova.do@knuba.edu.ua, ORCID: 0000-0002-9257-5703 \\ ${ }^{1}$ Киевский национальный университет строительства и архитектуры \\ пр. Воздухофлотский, 31, г. Киев, 03037, Украина
}

\begin{abstract}
Аннотация. На современном этапе развития строительной отрасли шаги по повышению эффективности инвестиционно-строительных проектов уже не могут рассматриваться вне контекста технологий информационного моделирования стройки. Сегодня одним из главных критериев оптимизации работы над инвестиционно-строительными проектами является уменьшение времени на поиск, проработку и согласование пространственной, финансовой и временной информации об объекте строительства, поэтому вопрос корректной организации информационного моделирования стройки вполне актуален.

В большинстве случаев задание на проектирование составляется по форме, приведенной в приложении Б ДБН А 2.2-2-2014, и носит формальный характер. Наличие задания на проектирование составленного с помощью предлагаемого ниже инструментария отражает тщательность проработки заказчиком инвестиционно-строительного проекта и снижает риски его реализации. Основой предлагаемой методики являются три составляющие встречного проектирования, такие как дезагрегация, агрегация и декомпозиция, от которых и происходит ее название - ДАД - подход. Выделение в составе стройки структурных элементов путем дезагрегации (анализа альтернативных вариантов) позволяет создать ее модель в виде иерархической структуры, состоящей из детальных и взаимосинхронизированных частей конфигурацию стройки. В соответствии с конфигурацией стройки иерархическая нумерация в дальнейшем отражается на всех стадиях проектирования и во всех его разделах, в т.ч. марках чертежей и локальных сметах. Это создает единую систему взаимосвязи и контроля разделов проекта. Создание конфигурации стройки в виде древовидной модели с иерархически пронумерованными элементами на предпроектной стадии позволяет применять ее на последующих этапах жизненного цикла объекта строительства в технологиях информационного моделирования. Применение ДАД - подхода при встречном проектировании призвано увеличить эффективность реализации инвестиционно-строительных проектов.

Ключевые слова: инвестиционно-строительный проект, информационное моделирование стройки, предпроектная стадия, ДАД - подход, дезагрегация.
\end{abstract}

Стаття надійшла до редакції 11.11.2021 